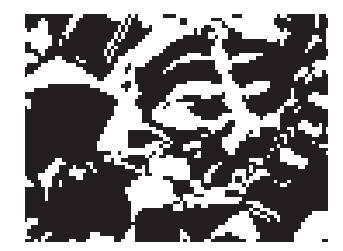

\title{
ACADEMIC ACHIEVEMENT AND STUDY SATISFACTION: THE CONTRIBUTION OF HIGH SCHOOL SUCCESS AND PERSONALITY
}

\author{
Vesna ANTIČEVIĆ \\ University of Split, University Department of Health Studies, Split \\ Goran KARDUM \\ Faculty of Humanities and Social Sciences, Split \\ Mira KLARIN \\ University of Zadar, Department of Health Studies, Zadar \\ †Joško SINDIK \\ Institute for Anthropological Research, Zagreb \\ Ivana BARAĆ \\ School of Medicine, Osijek \\ $\begin{aligned} \text { UDK: } & 373.3 .091 .279 .7(497.5):[378: 61] \\ & 378.011 .3-052(497.5): 159.942\end{aligned}$ \\ Izvorni znanstveni rad \\ Primlieno: 16. 2. 2017.
}

The aim of this study was to examine the role of high school success and personality traits in the academic achievement and study satisfaction among students of health studies. The Big Five questionnaire (BFQ) and Emotional competence questionnaire (UEK-45) were applied to 250 students, and the number of students' points when entering the study was obtained. The outcome measures were The study satisfaction scale (NSSS) and the number of passed exams in the 1st year. The results indicated two significant predictors for academic success: high school success $(\beta=0.18, p<0.01)$ and state matura success $(\beta=0.23, p<0.01)$ and also one predictor for study satisfaction: state matura success $(\beta=-0.16, p<0.01)$.

Keywords: emotional intelligence, Big Five, academic achievement, study satisfaction

$\triangle \quad$ Vesna Antičević, University of Split, University Department of Health Studies, Ruđera Boškovića 33, 21000 Split, Croatia. E-mail: vesna.anticevic@ozs.unist.hr 


\section{INTRODUCTION}

\section{Study satisfaction and academic achievement}

Research on study outcomes measured by students' satisfaction and academic achievement can be important for selection procedures when enrolling in a course, maintaining motivation during study, reaching higher performance levels, preventing students from dropping out and for their future professional efficiency. The outcomes of a study process can be evaluated using direct performance measures (e.g., average school marks) and indirect measures (e.g., students' study satisfaction).

Students' academic performance in higher education is affected by various socioeconomic, psychological, and environmental factors (Hijazi \& Naqvi, 2006). Previous studies noted that study success, as measured by college grade point average (GPA), was positively correlated with high school success as measured by high school GPA as well as achievement tests (Emme, 1942), and these variables continue to be identified as predictors of subsequent academic success (Hall, Smith, \& Chia, 2008; Zwick \& Sklar, 2005). Several studies also suggest that high school grades are better predictors of success than standardized test scores (Hoffman, 2002; Zheng, Saunders, Shelley, \& Whalen, 2002). More recent efforts have examined academic achievement, retention, and student satisfaction independently as measures of academic success (Hoffman \& Lowitzki, 2005). This enables the evaluation of not only students' knowledge but also the effectiveness of teaching processes, and perhaps, provides a gauge of student satisfaction (Martirosyan, Saxon, \& Wanjohi, 2014). Elliott and Shin (2002) describe student satisfaction as the favorability of a student's subjective evaluation of the various outcomes and experiences associated with education. The results of studies investigating the relationship between academic performance and study satisfaction were not always consistent. In some studies, a strong relationship between students' satisfaction and academic performance was found (Dhaqane \& Afrah, 2016), indicating that groups with higher academic achievement had higher satisfaction than groups with low academic achievement (Howard \& Maxwell, 1980). On the contrary, Blanz (2014) did not find a correlation between students' satisfaction and performance, whereas study satisfaction was determined by "noncognitive" factors such as motivation and course organization, while academic performance was influenced by "cognitive" factors such as final school grade and students' learning behavior. Although there is some evidence that psychological characteristics such as personality traits and emotional intelligence can also contribute to both academic success and student satisfaction, the results are inconsistent. 


\section{Personality traits, study satisfaction and academic success}

While Lounsbury, Saudargas, Gibson, \& Leong (2005) found that personality traits account for large portions of the variance in satisfaction with college, the meta-analytic study has shown that the relationship between personality traits, measured by The Big Five Questionnaire, and academic success depends on the success criterion. While neuroticism is related to academic satisfaction, conscientiousness correlates with grades. Extraversion, openness to experience, and agreeableness have no significant impact on academic success (Trapmann, Hell, Hirn, \& Schuler, 2007).

\section{Emotional intelligence, study satisfaction and academic success}

Emotional intelligence (EI) is defined as "the ability to perceive accurately, appraise, and express emotion; the ability to access and/or generate feelings when they facilitate thought; the ability to understand emotion and emotional knowledge; and the ability to regulate emotions so as to promote emotional and intellectual growth" (Mayer \& Salovey, 1997). The research results also show inconsistency regarding the relationship between emotional intelligence, study satisfaction and academic success. Some of them found that higher EI in students denotes better health, satisfaction with life and academic achievement (Fernandes \& Rego, 2004; MacCann, Fogarty, Zeidner, \& Roberts, 2011), while others found no correlation between EI and grade point average (Landau \& Merivoich, 2011; Hall \& West, 2011; Thompson, 2013).

The only two research studies that were found to investigate the relationship between EI and satisfaction of students did demonstrate that there was a positive correlation between EI and satisfaction (Grace, 2004; Holt, 2007).

\section{Personality traits and emotional intelligence in predicting achievement and satisfaction in health studies students}

Healthcare professionals have to be qualified to respond to the particular needs of persons with health difficulties. This means that, in addition to professional knowledge, they must have psychological characteristics that will enable greater success in studying and work in a medical practice. Patient care requires possession and continuous development of specific psychological characteristics, such as the ability to recognize own and patient's emotions, good emotional control, extraversion, conscientiousness, and mental openness. It is very likely that each of these features partly determine the choice of health profession but they need to be developed further during the study process and during work in healthcare practice. 
DRUŠ. ISTRAŽ. ZAGREB GOD. 27 (2018), BR. 2, STR. 243-260

ANTIČEVIĆ, V. ET AL.: CONTRIBUTION...
Pitt, Powis, Levett-Jones, and Hunter (2012) have identified four categories that potentially impact the nursing students' academic performance and attrition: demographic, academic, cognitive and personality/behavioural factors. The challenge for universities committed to students' success is to develop strategies aimed at addressing these factors that are appropriate to specific contexts and student cohorts. Specific personality traits and emotional competence of the students of health studies can have double impact on their professional and academic development: they can influence study outcome (Grace, 2004) and their ability to perform their work in a competent manner and also their own health and wellbeing (Wilson, 2014; Mikolajczak, Menil, \& Luminet, 2007; Birks, McKendree, \& Watt, 2009; Heydari, Kareshki, \& Armat, 2016).

The meta-analytic studies showed that academic success among university students is significantly related to the Big Five traits: conscientiousness, agreeableness, openness to experience (Poropat, 2009), and neuroticism (Trapmann et al., 2007) and that individuals who achieve higher results on the agreeableness scale choose helping, i.e. social professions (Nieken \& Störmer, 2010; Zenko, 2013). In nursing students, it has been found that extroverts are more satisfied with the study than introverts indicating that the study satisfaction levels are influenced by nursing students' personality types (Kim \& Han, 2014). Emotional intelligence is also associated to better clinical skills and academic achievements (Codier, Kooker, \& Shoultz, 2008) among medical students. In clinical practice, it is connected to greater empathy towards patients, doctor-patient relationship, clinical skills and patients' satisfaction (Arora et al., 2010). However, in the research by Olatoye, Akintunde, \& Yakasai (2010), negative association between emotional intelligence and academic achievement was established. In higher health education, Grace (2004) found that areas of emotional intelligence had an effect on certain satisfaction factors for undergraduate nursing students. Out of the total population of students, $71 \%$ were either extremely satisfied or satisfied with the university. More specifically, those who were very satisfied with professional development had lower scores on the use of emotion. However, those who had high scores on the use of emotion had higher levels of satisfaction in internal personal growth.

Based on the abovementioned empirical evidence, it can be assumed that, apart from academic achievement in high school, personality traits and emotional competence should also be estimated while selecting future health students. The purpose of this research was to examine the justifiability for improving the selection procedure while entering health studies in the Republic of Croatia. 
The aim of this study was to examine the role of secondary education and personality characteristics (personality traits and emotional competence) in the academic achievement and study satisfaction among Croatian students of health studies.

The first aim was to determine whether the sets of predictors (gender, success in high school and state graduation success, perceiving and understanding emotions, expressing and naming emotions and controlling and managing emotions, extraversion, agreeableness, conscientiousness, emotional stability and openness), contribute to the predicting of the results in the criterion of weighted average school mark (measure of academic achievement).

The second aim was to determine whether the same set of predictors contribute to the predicting results in the criterion satisfaction with study.

Accordingly, we formed the following expectations:

a) Based on the meta-analytic study where it was found that neuroticism was negatively related to satisfaction while conscientiousness positively correlated with grades (Trapmann et al., 2007), and based on the study that found extraverted nursing students to be more satisfied with the study (Kim \& Han, 2014), we set the first hypothesis: we expect a lower neuroticism and a higher extraversion to predict higher study satisfaction and a higher conscientiousness to predict better academic achievement in the students of health studies.

b) Based on previous findings, according to which the positive relationship between emotional intelligence with both academic achievement (Codier et al., 2008) and study satisfaction (Grace, 2004) were established, the second hypothesis was created: the higher levels of emotional intelligence (recognizing own emotions, recognizing other peoples' emotions and controlling emotions) will predict higher academic success and higher levels of study satisfaction.

c) Finally, according to the previous findings (Hall et al., 2008; Zwick \& Sklar, 2005), we expect that high school success indicators (average grades and results of state matura) will predict academic achievement in the students of health studies.

\section{MATERIALS AND METHODS}

Participants
The sample consisted of 250 students who participated in the research (78.8\% females and $21.2 \%$ males) aged from 19 to 36 $(M=22.3 ; S D=4.93)$. All participants were 1st year students of health studies (Nursing, Midwifery, Physiotherapy, Radiology Technology and Laboratory Diagnostics) at four Croatian universities: Split, Zadar, Dubrovnik and Osijek. The survey encompassed $93 \%$ of students from all four universities. The 
DRUŠ. ISTRAŽ. ZAGREB GOD. 27 (2018), BR. 2, STR. $243-260$

ANTIČEVIĆ, V. ET AL.: CONTRIBUTION...

\section{Measures}

largest number of participants were from the University of Osijek (45.2\%) and the University of Split (40\%), given that these two universities had the largest number of different health courses. About $9.2 \%$ of nursing students participated from the University of Zadar and 5.6\% of the nursing students were from the University of Dubrovnik. Proportional to the number of students and to the diversity of health courses, the sample consisted of the largest number of nursing students (48\%), then laboratory diagnostics (22\%) and physiotherapy (18\%). Radiologists and midwifery students were represented in the smallest proportion, each by $6 \%$. Personality traits questionnaire (BFQ) and emotional competence questionnaire (UEK-45) were applied at all universities at two time points: immediately after the beginning of the first year of study (October 2015) and at the end of the academic year (June and July 2016). The number of students' points when entering the study was also obtained. At the end of the academic year, the student satisfaction questionnaire was also applied and data on the number of passed 1st-year health studies exams were gathered. Questionnaires were used during classes. All questionnaires were in paper form and the participants completed the questionnaires in the presence of the examiner.

The students gave their consent stating that they agreed to participate in the research.

The Nursing Student Satisfaction Scale (NSSS) (Chen \& Lo, 2012) is designed to assist the nursing program in identifying the extent to which nursing students are satisfied with the nursing curriculum and teaching, professional social interaction and learning environment provided by the Bachelor of Science in Nursing (BSN) program. This scale consists of 30 statements. Each statement describes experience in the BSN program on a 5-point scale as follows: from 1 - "Not satisfied at all" to 5 - "Completely satisfied". All items of the NSSS met the criteria of the interitem and corrected item-total correlations coefficients, which indicated items contributed to the scale. For internal consistency reliability, the alpha of the total scale of the NSSS was 0.96 and each subscale was 0.91 for the curriculum, 0.90 for the faculty and 0.88 for the social interactions, and 0.87 for the environment. The results of construct validity and results of testing internal consistency type reliability are presented in Table 1 . While determining construct validity, exploratory factor analysis was applied. Multiple principal components extraction criteria were applied: Guttman-Kaiser criterion, Scree plot test and Parallel analysis. All three criteria suggested the single factor solution. 


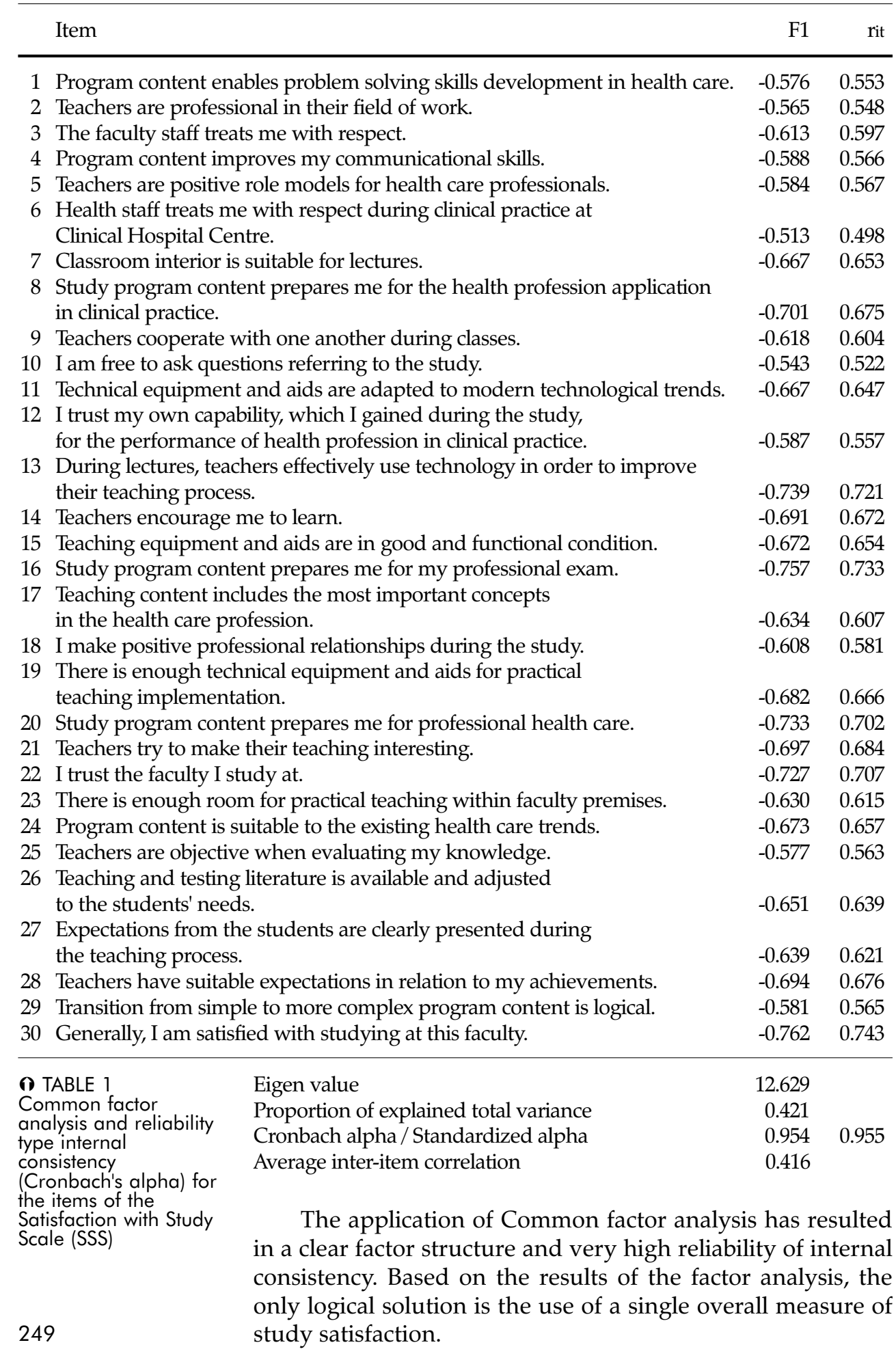


DRUŠ. ISTRAŽ. ZAGREB GOD. 27 (2018), BR. 2, STR. $243-260$

ANTIČEVIĆ, V. ET AL: CONTRIBUTION...

\section{RESULTS}

The Big Five Questionnaire (Big Five Questionnaire - BFQ; Caprara, Barbaranelli, \& Borgogni, 2005) was used for personality traits testing. The Big Five Questionnaire was used for the evaluation of five big personality dimensions within the Five-Factor Model. In accordance with the Five-Factor Model, the questionnaire consists of the following scales: Energy (E), Comfort (U), Conscientiousness (C), Emotional Stability (ES), Mental Openness (MO) and, additionally Lie (L) scale. The questionnaire consists of 132 statements. The respondents' task is to state their level of agreement with each statement on a scale from 1 to 5 ( 1 - completely untrue for me, 5 - completely true for me). Participants' results are determined by adding up evaluations for suitable parts of each questionnaire dimension. Internal consistency coefficients (Cronbach $\alpha$ ) for certain personality dimensions in this research range from 0.83 to 0.94 and are considered satisfying.

Emotional Competence Questionnaire UEK-45 is a measure of emotional intelligence (Takšić, 2002). It consists of three subscales: Recognizing/understanding emotions (R/U) (15 items), Expressing/naming emotions (E/N) (14 items) and Regulating/ managing emotions $(\mathrm{R} / \mathrm{M})$ (16 items). The respondent has to estimate how much a certain statement refers to him/her on a 5 -point Likert scale ( 1 - I completely disagree to 5 - I completely agree). Psychometric characteristics of UEK-45 are mostly good. The reliability coefficients for each subscale range from 0.88 to 0.92 . (Takšić, 2002). The intercorrelations between certain subscales are between 0.35 and 0.51 , and the total result can be formed as a measure for general emotional competence with reliability between 0.87 and 0.92 .

Data on the number of state matura exam points and average high school mark were obtained from the students' records at the faculties.

Weighted average mark at the faculty was obtained through the following formula: total marks $x$ ECTS. Course marks were obtained from the faculty system records.

In order to establish the correlations between all relevant variables in this study, Pearson's correlation coefficients were calculated. A relatively large number of correlations are statistically significant but low, particularly between predictor and criterion variables, which justifies the application of a backward stepwise regression analysis. Distribution and variability of criterion variables (weighted average school mark and study satisfaction) as well as predictors (success in high school and state matura) were mostly normally distributed with lower 
deviations (K.S. test, $p>0,01$ ) (Table 2). The correlations between the variables are shown in Table 3.

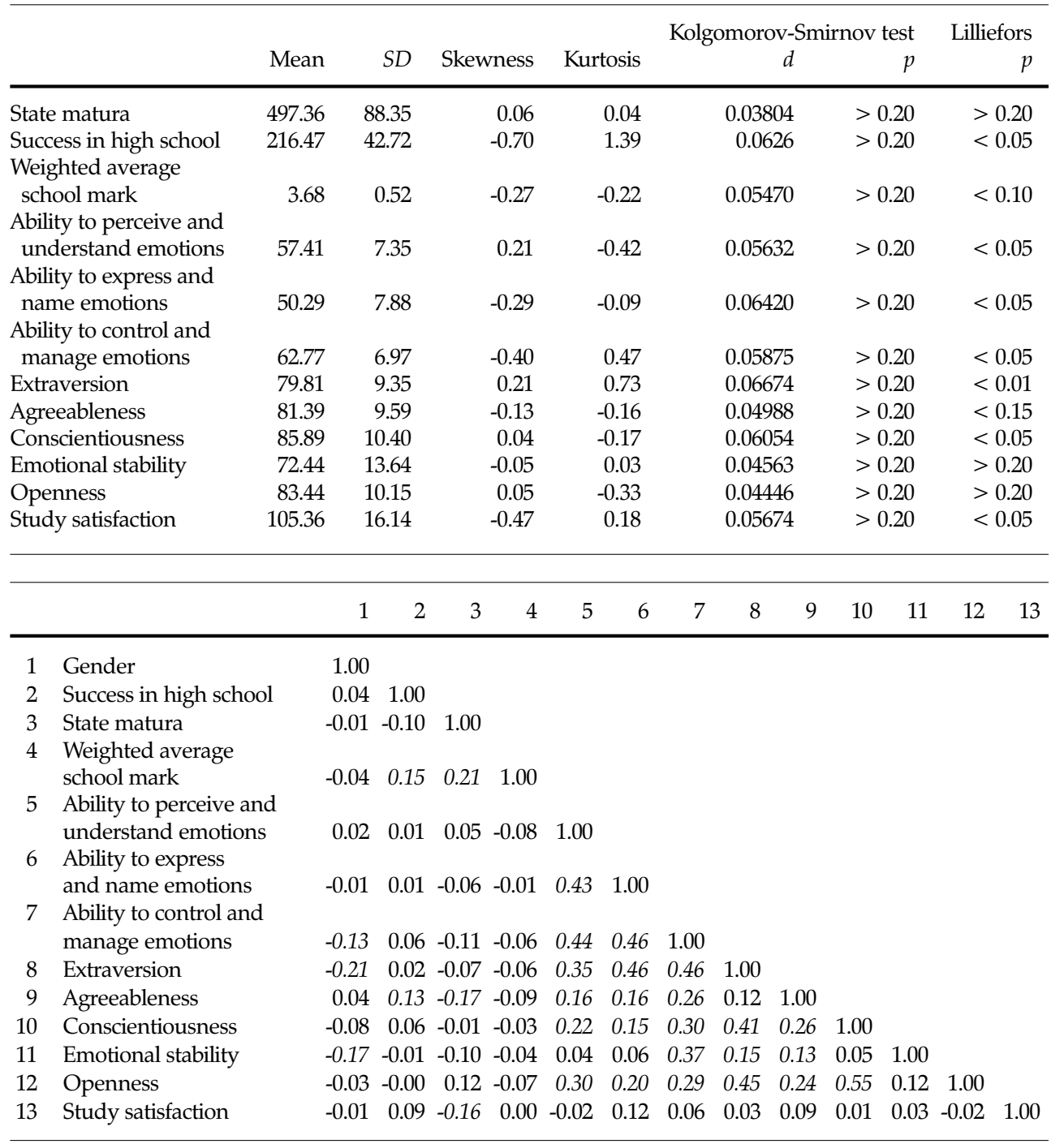

$r=0.125, p<0.05 ; r=0.164, p<0.01$

DO TABLE 2

Descriptive values of the examined variables

\section{(1) TABLE 3}

Correlation between high school success personality traits (BFQ), emotional competence (ECS) and study satisfaction (NSSS)
In the first step of backward stepwise regression analysis, predictors for the criterion Weighted average mark were as follows: gender, high school success and state matura success, ability to perceive and understand emotions, ability to express and name emotions, ability to control and manage emotions, extraversion, agreeableness, conscientiousness, emotional stability, openness, study satisfaction. In the final step and for the same criterion, the predictors were success in high school and state matura (Table 4). 
DRUŠ. ISTRAŽ. ZAGREB GOD. 27 (2018), BR. 2, STR. $243-260$

ANTIČEVIĆ, V. ET AL.: CONTRIBUTION...
The results presented in Table 4 showed that the only significant predictors of academic success (Weighted average school mark) were as follows: high school success (average mark from all subjects through four high school grades) and state matura success. The predictions were in the expected direction meaning that the students who had better school success and better matura results achieved better academic success. State matura success had a more predictive validity for academic success than high school success. However, state matura success and high school success were not statistically significantly connected. Furthermore, adding emotional competence and personality traits (Big Five) measures did not significantly contribute to the academic success variance explanation (no significant predictors).

In the backward stepwise regression analysis, the same variables were taken as predictors for the study satisfaction criterion in the same steps as for the previously analysed criterion of weighted average mark (Table 5).

\begin{tabular}{lccc}
\hline Variables in model (first step) & $\beta$ & $\mathrm{t}$ & $p$ \\
\hline Gender & -0.048 & -0.735 & 0.463 \\
Success in high school & 0.183 & 2.886 & $0.004^{* *}$ \\
State matura & 0.234 & 3.548 & $0.000^{* *}$ \\
Ability to perceive and understand emotions & -0.088 & -1.181 & 0.239 \\
Ability to express and name emotions & 0.073 & 0.943 & 0.347 \\
Ability to control and manage emotions & -0.004 & -0.049 & 0.961 \\
Extraversion & -0.032 & -0.385 & 0.701 \\
Agreeableness & -0.057 & -0.829 & 0.408 \\
Conscientiousness & 0.039 & 0.498 & 0.619 \\
Emotional stability & -0.006 & -0.087 & 0.930 \\
Openness & -0.076 & -0.938 & 0.349 \\
Study satisfaction & 0.016 & 0.249 & 0.804 \\
& & & \\
Variables in model (final step) & $0.311 / \mathrm{F}(12,233)=2.085 / p<0.019^{* *}$ \\
Success in high school & & & \\
State matura & 0.175 & 2.822 & $0.005^{* *}$ \\
& 0.226 & 3.641 & $0.000^{* *}$ \\
& $R=0.272 / \mathrm{F}(2,243)=9.708 / p<0.0001^{* *}$
\end{tabular}

(1) TABLE 4

Summary of backward stepwise regression analysis with Weighted average school mark as criterion variable
Legend: standardized coefficients of partial regression are presented $(\beta)$ with the corresponding statistical significances; ${ }^{*} p<0.05,{ }^{* *} p<0.01$.

When we consider the study satisfaction criterion (Table 5), only state matura was a significant predictor $(p<0.01)$ in the final step, but in the negative direction. The students who had better matura results also had lower study satisfaction. Emotional competence and personality traits (Big Five) measures did not significantly contribute to the study satisfaction criterion. 


\begin{tabular}{lrrr}
\hline Variables in model (first step) & \multicolumn{1}{c}{$\mathrm{t}$} & $\mathrm{p}$ \\
\hline Gender & -0.015 & -0.218 & 0.828 \\
Success in high school & 0.067 & 1.021 & 0.308 \\
State matura & -0.135 & -1.956 & 0.052 \\
Weighted average school mark & 0.017 & 0.249 & 0.804 \\
Ability to perceive and understand emotions & -0.069 & -0.896 & 0.371 \\
Ability to express and name emotions & 0.146 & 1.845 & 0.066 \\
Ability to control and manage emotions & 0.000 & 0.003 & 0.998 \\
Extraversion & -0.031 & -0.365 & 0.715 \\
Agreeableness & 0.054 & 0.766 & 0.445 \\
Conscientiousness & 0.002 & 0.029 & 0.977 \\
Emotional stability & 0.012 & 0.175 & 0.861 \\
Openness & -0.018 & -0.216 & 0.829 \\
& $R=0.226 / \mathrm{F}(12,233)=1.045 / p<0.408$ \\
Variables in model (final step) & & & \\
$\quad$ State matura & -0.159 & -2.526 & $0.012^{* *}$ \\
TABLE 5 & $R=0.159 / \mathrm{F}(1,244)=6.3835 / p<0.0012^{* *}$ \\
Summary of backward & &
\end{tabular}

\section{DISCUSSION}

In this study, only two statistically significant predictors of academic success were identified: high school success and state matura success in the expected direction which means that the students with better high school success and better state matura results achieved better academic success at the end of the academic year. This result is in accordance with previous findings (Hallet al., 2008; Zwick \& Sklar, 2005) and confirms our hypothesis that high school success indicators (average grades and results of state matura) will predict academic achievement in the students of health studies.

However, there is no statistically significant correlation between state matura success and school marks success. This finding was in accordance with the expectation since higher correlation values between these two high school success indicators can be low due to the homogeneity of students enrolling in a certain study program and consequently less variability in school success indicators. A significant higher positive correlation can be expected only if the analysis includes a more heterogeneous students' sample and study programs which are both less and more attractive.

From a statistical point of view, the sample of respondents in this research is simply too homogenous. Therefore, it could not be expected that there would be significant interindividual variability per personality traits. This variability ab- 
DRUŠ. ISTRAŽ. ZAGREB GOD. 27 (2018), BR. 2, STR. 243-260

ANTIČEVIĆ, V. ET AL.: CONTRIBUTION... sence automatically decreased the possibility of significant correlations with any other variables (similar as for absence of connection between school success and matura success). It can be assumed that the students of health studies mostly come from a very similar social and demographic background (Jukić, Antičević, Švaljug, \& Orlandini, 2016). This explains decreased variability in terms of different characteristics.

The aspects of emotional competence and personality traits (Big Five) measures did not significantly contribute to the academic success variance explanation (no significant predictors). This finding does not support the previous findings where academic achievement was positively related to the Big Five traits: conscientiousness (Trapmann et al., 2007; Poropat, 2009), agreeableness, openness to experience (Poropat, 2009), neuroticism (Trapmann et al., 2007) and to emotional intelligence (Codier et al., 2008). One of the possible reasons could be the assumption that emotional intelligence/competence questionnaires (including UEK-45) do not measure true emotional competence since similar constructs simply cannot be measured with the self-evaluation method. It is more likely that UEK-45 measures self-criticism rather than any competences. For example, individuals with higher academic (and probably emotional) intelligence tend to underestimate themselves due to a higher level of self-criticism in relation to those with lower intelligence who are less self-critical or use different personality defence mechanisms such as rationalization (Kluemper, 2008).

The next explanation of the obtained results is based on additional testing of self-evaluation validity. Personality traits as well as the results which are obtained from the lying scale are inter-connected with positive correlations (low but statistically significant). It is likely that there is a significant part of variance which is conditioned by socially desirable respondents' answers due to the perception of all tested personality traits as desirable in our society (Kluemper, 2008). There can also be an interpretation for the small correlation between state matura success and average high school success. High school success is a clearly defined and reliable variable while state matura success has its deficiencies. Although, in accordance with the importance percentage, the existing state matura success results from different cities are equalized, we cannot know with certainty how much importance a particular study program pays to certain subjects (with potential special achievements which are also graded). In any case, state matura success (despite its deficiencies) and average high school success proved to be statistically significant predictors for academic success and, as such, they are important for this research.

In terms of the other research objective, there was a statistically significant contribution of the state matura, with a 
DRUŠ. ISTRAŽ. ZAGREB GOD. 27 (2018), BR. 2 STR. 243-260

ANTIČEVIĆ, V. ET AL.: CONTRIBUTION.. negative correlation to study satisfaction as a criterion variable. It was shown that other predictor groups (emotional competence and personality traits) did not statistically contribute to the predicted results when we analysed the study satisfaction criterion. This does not support the previous findings according to which neuroticism is related to academic satisfaction, (Trapmann et al., 2007) and higher emotional intelligence is related with study satisfaction (Grace, 2004).

State matura was only a significant predictor of study satisfaction in the negative direction, meaning that the students who had better state matura results were less satisfied with their study. We can assume that those students had higher expectations regarding the study process which were not fulfilled. The most likely and most logical interpretation of this result can be explained by the assumption that only a small number of students can really estimate study satisfaction since they did not have clear expectations before they entered the faculty. Furthermore, there is a possibility that students enrol in health studies for pragmatic motives, such as wider employment opportunities, easier college or specific field of study for easier employment (Kesić \& Previšić, 1998) and not due to internal motivation. As with the previous analysis, another potential reason can be the homogeneity of students who enter a certain type of study program in accordance with a number of characteristics. Consequently, there is not enough variability in terms of almost all tested variables, including study satisfaction.

One of the reasons for the absence of statistically significant predictors of study satisfaction can be the fact that the students of the most attractive study programs (with high average mark and state matura results) averagely have lower study satisfaction. Although the programs attended by students of the most attractive study programs are probably the ones with the greatest quality (in terms of teaching staff, study requirements and material preconditions), due to higher ambitions, these students also have higher expectations from their teachers and programs. Unlike them, students of less attractive programs (with lower expectations) averagely give the highest marks to their teachers and programs and therefore, consider their study satisfaction significantly higher (Croatian Agency for Science and Higher Education, 2015).

Finally, study satisfaction was treated as a one-dimensional variable in this research. In the original factor structure suggested by the author (Chen \& Lo, 2012), study satisfaction should be operationalized as a three-factor construct. However, in this research, the results of exploratory factor analysis clearly show the justifiability of only one study satisfaction factor in accordance with all used criteria for significant factor reservation. 
DRUŠ. ISTRAŽ. ZAGREB GOD. 27 (2018), BR. 2, STR. 243-260

ANTIČEVIĆ, V. ET AL. CONTRIBUTION...

\section{CONCLUSION}

The advantage of this research is the fact that the sample of students from almost all Croatian university studies was used. This sample can be considered as representative for the population of 1st year health study students in the Republic of Croatia. This type of research is implemented for the first time in the Republic of Croatia. Until now, the relationship between personality traits and emotional competence with study satisfaction and success has not been tested.

The main research limitation is the homogeneity of the health study students sample since this can cause bias and influence the research results. The following limitation stems from the fact that socio-demographic data (except gender) were not collected, based on which it could be possible to get more concise conclusions about the effects of sample homogeneity on the obtained results. Another limitation refers to the usage of self-descriptive techniques, especially for testing emotional competence as a characteristic which is subject to situational factors. Future research should include a more heterogeneous sample consisting of students from "desirable" and "less desirable" faculties. This would result in greater variability and results validity.

Despite the fact that this research did not discover the connection between personality traits and emotional competence on one side and study satisfaction and success on the other, it could serve as stimulation for further improvement of the additional selection procedure for students who are to enter health studies with the aim of ensuring quality health professionals.

Predictor importance of three variable groups (high school success, personality traits and emotional competence) has been determined for the academic success and study satisfaction criteria among first-year students of health studies.

As for the first research objective, it was proved that most predictors used in this research did not predict the academic success criterion (weighted average mark). However, the only statistically significant predictor for the academic success criterion were high school success and state matura success in the expected direction meaning that the students who achieved better high school success and state matura results had better academic success in their first year of study. However, in terms of the second research objective, it was proven that the same predictor groups did not predict study satisfaction. The exception is state matura success as the only variable which predicts satisfaction with study, but in the negative direction. Suggested explanations primarily refer to respondents' sample homogeneity and problematic usage of the emotional competence self-evaluation method. 


\section{Acknowledgments}

A survey was conducted within the project entitled "Development of occupational standards/qualifications for the improvement of health study programs" HR3.1.15-0051, supported by the Ministry of Science and Education and financed by the European Social Fund.

This article is dedicated to dear colleague Joško Sindik who recently passed away, and who gave a significant human and professional contribution during the implementation of the project.

\section{REFERENCES}

Arora, S., Ashrafian, H., Davis, R., Athanasiou, T., Darzi, A., \& Sevdalis, N. (2010). Emotional intelligence in medicine: A systematic review through the context of the ACGME competencies. Medical Education, 44(8), 749-764. https://doi.org/10.1111/j.1365-2923.2010.03709.x

Birks, Y., McKendree, J., \& Watt, I. (2009). Emotional intelligence and perceived stress in healthcare students: A multi-institutional, multi-professional survey. BMC Medical Education, 9(61), 1-8. https://doi. org/10.1186/1472-6920-9-61

Blanz, M. (2014). How do study satisfaction and academic performance interrelate? An investigation with students of Social Work programs. European Journal of Social Work, 17(2), 281-292. https://doi.org/ 10.1080/13691457.2013.784190

Caprara, G. V., Barbaranelli, C., \& Borgogni, L. (2005). Big Five Upitnik [Big Five Questionnaire - BFQ]. Jastrebarsko: Naklada Slap.

Chen, H. C., \& Lo, H. S. (2012). Development and psychometric testing of the nursing student satisfaction scale for the associate nursing programs. Journal of Nursing Education and Practice, 2(3), 25-37. https://doi. org/10.5430/jnep.v2n3p25

Codier, E., Kooker, B. M., \& Shoultz, J. (2008). Measuring the emotional intelligence of clinical staff nurses: An approach for improving the clinical care environment. Nursing Administration Quarterly, 32(1), 8-14. https://doi.org/10.1097/01.NAQ.0000305942.38816.3b

Croatian Agency for Science and Higher Education (2015). Student satisfaction with the study programs and readiness for labour market: Research results.

Dhaqane, M. K., \& Afrah, N. A. (2016). Satisfaction of students and academic performance in Benadir university. Journal of Education and Practice, 7(24), 59-63.

Elliott, K. M., \& Shin, D. (2002). Student satisfaction: An alternative approach to assessing this important concept. Journal of Higher Education Policy and Management, 24(2), 197-209. https://doi.org/10.1080/ 1360080022000013518

Emme, E. E. (1942). Predicting college success. The Journal of Higher Education, 13(5), 263-267. https://doi.org/10.2307/1974937

Fernandes, C., \& Rego, A. (2004). How emotional intelligence explains students' life satisfaction, physical ill-health and academic achievement. Paper presented at the European Conference on Educational Re- 
DRUŠ. ISTRAŽ. ZAGREB GOD. 27 (2018), BR. 2, STR. $243-260$

ANTIČEVIĆ, V. ET AL. CONTRIBUTION... search, University of Crete, 22-25 September 2004, Network 22 Teaching and Learning in Higher Education.

Grace, F. R. (2004). The relationship between student satisfaction and emotional intelligence among undergraduate students enrolled in nursing programs. Available at ProQuest Digital Dissertations Database (AAT 3151785).

Hall, C., Smith, K., \& Chia, R. (2008). Cognitive and personality factors in relation to the timely completion of a degree. College Student Journal, 42, 1087-1098.

Hall, P. C., \& West, J. H. (2011). Potential predictors of student teaching performance: Considering emotional intelligence. Issues in Educational Research, 21(2), 145-161.

Heydari, A., Kareshki, H., \& Armat, M. R. (2016). Is nurses' professional competence related to their personality and emotional intelligence? A cross-sectional study. Journal of Caring Sciences, 5(2), 121-132. https://doi.org/10.15171/jcs.2016.013

Hijazi, S. T., \& Naqvi, S. M. M. (2006). Factors affecting students' performance. Bangladesh e-Journal of Sociology, 3(1), 1-10.

Hoffman, J. L. (2002). The impact of student cocurricular involvement on student success: Racial and religious differences. Journal of College Student Development, 43(5), 712-739.

Hoffman J. L., \& Lowitzki, K. E. (2005). Predicting college success with high school grades and test scores: Limitations for minority students. The Review of Higher Education, 28(4), 455-474. https://doi.org/ 10.1353/rhe.2005.0042

Holt, S. (2007). Emotional intelligence and academic achievement in higher education. Available at ProQuest Digital Dissertations Database (AAT 3256101).

Howard, G. S., \& Maxwell, S. E. (1980). Correlation between student satisfaction and grades: A case of mistaken causation? Journal of Educational Psychology, 72(6), 810-820. https://doi.org/10.1037/0022-0663. 72.6 .810

Jukić, S., Antičević, V., Švaljug, D., \& Orlandini, R. (2016). Emocionalna kompetentnost i empatija studenata zdravstvenih studija $u$ Splitu [Emotional competency and empathy in students of health studies]. Primaljski vjesnik, 20, 7-12.

Kesić, T. \& Previšić, J. (1998). Motivi upisa i zadovoljstvo nastavnim programom studenata ekonomskih i elektrotehničkih fakulteta $\mathrm{u}$ Hrvatskoj [Students' motives for enrollment in and satisfaction with the curricula of faculties of economics and electrical engineering in Croatia]. Društvena istraživanja, 7(4-5), 731-746.

Kim, M., \& Han, S. (2014). Relationships between the Myers-Briggs type indicator personality profiling, academic performance and student satisfaction in nursing students. International Journal of Bio-Science and Bio-Technology, 6(6), 1-12. https://doi.org/10.14257/ijbsbt.2014.6.6.01

Kluemper, D. H. (2008). Trait emotional intelligence: The impact of core-self evaluations and social desirability. Personality and Individual Differences. 44(6), 1402-1412. https://doi.org/10.1016/j.paid.2007.12.008 
DRUŠ. ISTRAŽ. ZAGREB GOD. 27 (2018), BR. 2 STR. 243-260

ANTIČEVIĆ, V. ET AL.: CONTRIBUTION..
Landau, J., \& Meirovich, G. (2011). Development of students' emotional intelligence: Participative classroom environments in higher education. Academy of Educational Leadership Journal, 15(3), 89-104.

Lounsbury, J. W., Saudargas, R. A., Gibson, L. W., \& Leong, F. T. (2005). An investigation of broad and narrow personality traits in relation to general and domain-specific life satisfaction of college students. Research in Higher Education, 46(6), 707-729. https://doi.org/10.1007/ s11162-004-4140-6

MacCann, C., Fogarty, G. J., Zeidner, M., \& Roberts, R. D. (2011). Coping mediates the relationship between emotional intelligence (EI) and academic achievement. Contemporary Educational Psychology, 36(1), 60-70. https://doi.org/10.1016/j.cedpsych.2010.11.002

Martirosyan, N. M., Saxon, D. P., \& Wanjohi, R. (2014). Student satisfaction and academic performance in Armenian higher education. American International Journal of Contemporary Research, 4(2), 1-5.

Mayer, J. D., \& Salovey, P. (1997). What is emotional intelligence? In P. Salovey \& D. J. Sluyter (Eds.), Emotional development and emotional intelligence: Educational implications (pp. 3-34). New York: Harper Collins.

Mikolajczak, M., Menil, C., \& Luminet, O. (2007). Explaining the protective effect of trait emotional intelligence regarding occupational stress: Exploration of emotional labour processes. Journal of Research in Personality, 41(5), 1107-1117. https://doi.org/10.1016/j.jrp.2007.01.003

Nieken, P., \& Störmer, S. (2010). Personality as predictor of occupational choice: Empirical evidence from Germany. Diskussionspapiere des Schwerpunktes Unternehmensführung am Fachbereich BWL, 2(8), 1-29.

Olatoye, R. Ademola, Akintunde, S. O., \& Yakasai, M. I. (2010). Emotional intelligence, creativity and academic achievement of business administration students. Electronic Journal of Research in Educational Psychology, 8(2), 763-786.

Pitt, V., Powis, D., Levett-Jones, T., \& Hunter, S. (2012). Factors influencing nursing students' academic and clinical performance and attrition: An integrative literature review. Nurse Education Today, 32(8), 903-913. https://doi.org/10.1016/j.nedt.2012.04.011

Poropat, A. E. (2009). A meta-analysis of the five-factor model of personality and academic performance. Psychological Bulletin, 135(2), 322-338. https://doi.org/10.1037/a0014996

Takšić, V. (2002). Skala emocionalne kompetentnosti [Emotional competence scale]. In K. Lacković-Grgin, V. Ćubela \& Z. Penezić (Eds.), Zbirka psihologijskih skala i upitnika [Collection of psychological scales and questionnaires]. Zadar: Filozofski fakultet $\mathrm{u}$ Zadru.

Thompson, C. (2013). Emotional intelligence and graduate student satisfaction at online institutions of higher education. (Unpublished Doctoral Dissertation). Walden University, Minneapolis.

Trapmann, S., Hell, B., Hirn, J. W., \& Schuler, H. (2007). Meta-analysis of the relationship between the Big Five and academic success at university. Zeitschrift Für Psychologie / Journal of Psychology, 215(2), 132-151. https://doi.org/10.1027/0044-3409.215.2.132

Wilson, J. (2014). The awareness of emotional intelligence by nurses and support workers in an acute hospital setting. Journal of Health Sciences, 2(9), 458-464. 
DRUŠ. ISTRAŽ. ZAGREB GOD. 27 (2018), BR. 2, STR. $243-260$

ANTIČEVIĆ, V. ET AL. CONTRIBUTION...
Zenko, S. (2013). Comparison of high school students' personality traits in the helping professions and those of general education Croatian Journal of Education: Hrvatski časopis za odgoj i obrazovanje, 15(3), 205-218.

Zheng, J. L., Saunders, K. P., Shelley II, M. C., \& Whalen, D. F. (2002). Predictors of academic success for freshmen residence hall students. Journal of College Student Development, 43(2), 267-283.

Zwick, R., \& Sklar, J. C. (2005). Predicting college grades and degree completion using high school grades and SAT scores: The role of student ethnicity and first language. American Educational Research Journal, 42(3), 439-464. https://doi.org/10.3102/00028312042003439

\section{Akademsko postignuće i zadovoljstvo studijem: doprinos uspjeha u srednjoi školi i osobina ličnosti}

Vesna ANTIČEVIĆ

Sveučilište u Splitu, Sveučilišni odjel zdravstvenih studija, Split

\section{Goran KARDUM}

Filozofski fakultet, Split

Mira KLARIN

Sveučilište u Zadru, Odjel za zdravstvene studije, Zadar

†Joško SINDIK

Institut za antropologiju, Zagreb

Ivana BARAĆ

Medicinski fakultet, Osijek

Cili provedene studije bio je ispitati doprinos uspieha u srednjoj školi i osobina ličnosti akademskom postignuću i zadovoljstvu studijem kod studenata zdravstvenih studija. Big Five upitnik (BFQ) i Upitnik emocionalne kompetentnosti (UEK-45) primijenjeni su na 250 studenata te je prikupljen broj bodova prilikom upisa na studii. Kao mjere ishoda korištene su Skala zadovoljstva studijem (NSSS) i broj položenih ispita na kraju 1. godine. Rezultati ukazuju na dva statistički značajna prediktora akademskog uspjeha: uspjeh u srednjoi školi $(\beta=0.18, p<0.01)$ i uspjeh na državnoj maturi $(\beta=0.23, p<0.01)$. Uspjeh na državnoj maturi jedini je prediktor zadovolistva studijem $(\beta=-0.16, p<0.01)$.

Ključne riječi: emocionalna inteligencija, Big Five upitnik, akademsko postignuće, zadovoljstvo studijem

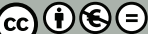

Međunarodna licenca / International License:

Creative Commons Attribution-NonCommercial-NoDerivatives 4.0. 